\title{
Maintenance procedures and definition of limit states for exterior wood coatings
}

\author{
Gerhard Grüll • Michael Truskaller • \\ Laurence Podgorski • Susanne Bollmus • \\ Florian Tscherne
}

Received: 16 October 2009 / Published online: 30 July 2010

(c) Springer-Verlag 2010

\begin{abstract}
Maintenance procedures of different wood coating systems were studied in field exposure trials with coated balcony constructions. Maintenance coatings were applied on one half of each of the balcony parts after 18 months and assessed after 24 months of total exposure time. It was found that the opaque white coating systems were the most durable ones reaching long intervals of required maintenance. For systems with lower durability on the maintained surfaces further degradation of the coatings was prevented. Different characteristics were observed for film forming and non film forming semi-transparent varnishes. Definitions of a series of limit states for coating systems on wood were suggested including esthetical limits and three levels of durability limits. Film forming coatings can reach two durability limits, i.e. the maintenance interval and the renovation interval. For non film forming coatings there is only one limit state of coating durability where maintenance is needed. The third durability limit is related to the coated substrate, i.e. the wood component, by the onset of decay in wood.
\end{abstract}

\section{Wartungsmaßnahmen und Definition von Grenzzuständen für Holzaußenbeschichtungen}

Zusammenfassung Wartungsmaßnahmen von verschiedenen Beschichtungssystemen für Holz wurden in Freilandbe-

G. Grüll $(\bowtie) \cdot$ M. Truskaller · F. Tscherne

Holzforschung Austria, Franz Grill Strasse 7, 1030 Wien, Austria

e-mail: g.gruell@holzforschung.at

L. Podgorski

FCBA, Allée de Boutaut, BP227, 33028 Bordeaux Cedex, France

S. Bollmus

Wood Biology and Wood Products, University of Göttingen,

Büsgenweg 4, 37077 Göttingen, Germany witterungsversuchen mit beschichteten Balkonkonstruktionen untersucht. Wartungsanstriche wurden auf eine Hälfte jedes Balkonteiles nach 18 Monaten Bewitterung aufgetragen und nach 24 Monaten eine Beurteilung durchgeführt. Die deckend weißen Beschichtungssysteme waren am dauerhaftesten und erreichten lange Wartungsintervalle. Bei Systemen mit geringerer Dauerhaftigkeit wurde auf den gewarteten Flächen ein Fortschreiten von Schäden verhindert. Bei filmbildenden und nicht filmbildenden Beschichtungen wurden unterschiedliche Eigenschaften beobachtet. Definitionen von Grenzzuständen von Holzbeschichtungen wurden erstellt und beinhalten ästhetische Grenzen und drei Stufen von Dauerhaftigkeitsgrenzen. Filmbildende Beschichtungen können zwei Dauerhaftigkeitsgrenzen erreichen, nämlich den Wartungsintervall und den Renovierungsintervall. Bei nicht filmbildenden Beschichtungen gibt es nur eine Dauerhaftigkeitsgrenze, die eine Wartung erfordert. Die dritte Dauerhaftigkeitsgrenze bezieht sich auf das beschichtete Substrat, also den Holzteil, und ist durch den Beginn des Holzabbaues gekennzeichnet.

\section{Introduction}

All materials subjected to weathering exposure undergo certain degradation processes (Kutz 2005). To prevent surface degradation of wood products in exterior use coatings are applied that must fulfill a number of specific functions in order to protect the wooden substrate. A suitable coating system for wood must provide sufficient protection against UV-light, moisture, micro-organisms and physical parameters (Richter 1988; Ekstedt 2002; Brandstätter et al. 2002; De Meijer 2002; Schober et al. 2006). With these functions coating systems contribute to protect the substrate and to enhance the durability of the coated wooden component. 
Coating systems themselves, however, also underly degradation caused by several weathering factors. In particular UV-light and moisture are harmful for binder polymers of coatings and long term exposure leads to increasing brittleness, chalking, cracking and flaking (De Meijer 2002; Hayoz et al. 2003; Tretter 2004; Bulian et al. 2004; Schaller and Rogez 2007). The dimensional movement, cracking and surface degradation of the wood substrate also negatively influence coating durability.

The durability and protective properties of coatings on exterior wood are limited in time which results in a service life of the coating that usually is different from the service life of the wood component. The durability of wood coatings has been investigated in numerous studies. It is influenced by a variety of factors, where coating formulation, film thickness, pigmentation, use of light stabilizers, substrate properties and design as well as exposure conditions play the most important roles (Sell 2003; Ekstedt 2002; De Meijer 2002; Richter 2006; Schober et al. 2006).

Maintenance is vital to retain the integrity of the coating film and prolongs its service life. It was defined by MacKenzie et al. (2007) in the following way: The purpose of maintenance is to ensure that the original condition of a material will remain intact so that it can continue to effectively perform its intended function be it functional or for aesthetic reasons. When degradation has progressed until defects of the coating occur, renovation is needed to repair the coating film and restore its protective functions. A coating system on wood can be maintained and renovated several times which contributes to an extended service life of wood components (Grüll 2003; Tscherne and Grüll 2005). It is, however, for professional painters as well as for end-users very difficult to determine the proper time to apply a maintenance coating before weathering leads to defects that would require renovation. Guidance on alterations of coated surfaces that indicate the need and can be tolerated for maintenance work is rare. These alterations or defects that are signs for required actions to prolong the intended function of a wood component can be regarded as limit states, where subsequent limits are reached and-if no action is undertaken-passed over time until the wood coating or the wood component finally is severely degraded. Estimating service life of wood coatings inherently needs a definition of the end of service life, which is the point in time when a protective function of the coating gets lost. The European Construction Products Directive (CPD) (1989) established a concept of working life of works and products and thereby initiated the development of methods for service life planning where acceptable levels of performance, i.e., limit states, are required (Englund 2009).

In France the French standard T30-806 (1991) Paints and varnishes - painting of building - specimen contract for periodic maintenance recommends a regular inspection of coatings in order to maintain their aspects and performances and avoid a complete renovation which is always more expensive than regular inspections and re-coating. This standard gives a model of such a contract between the building contractor and the main contractor of the building to be inspected. This model lists the obligations of the contracting parties. However it does not detail what kind of degradation and what level of degradation require maintenance. Therefore, periodic maintenance schemes are useful but should be defined in a better way with the use of limit sates.

The objective of the present work was to investigate maintenance procedures of different wood coating systems and to gather experience on the proper time intervals for maintenance. Based on this experience it was intended to develop definitions of limit states of wood coatings that determine intervals of maintenance, renovation and replacement. The long-term performance of maintained wood coatings was not within the main focus of the present paper and therefore, these results will be reported separately.

\section{Materials and methods}

Fifteen balcony constructions made of Norway spruce wood (Picea abies) with the same design were coated with different coating systems and exposed to natural weathering at Holzforschung Austria in Vienna starting at 20.11.2003. One more balcony construction was left uncoated. The shape of the constructions was triple-sided with the sides facing east, south and west and they comprised no floorings (Figs. 1 and 2). The parts represented typical balcony constructions as widely used in Austria and southern Germany. On the top sides of the hand rails a few patches as

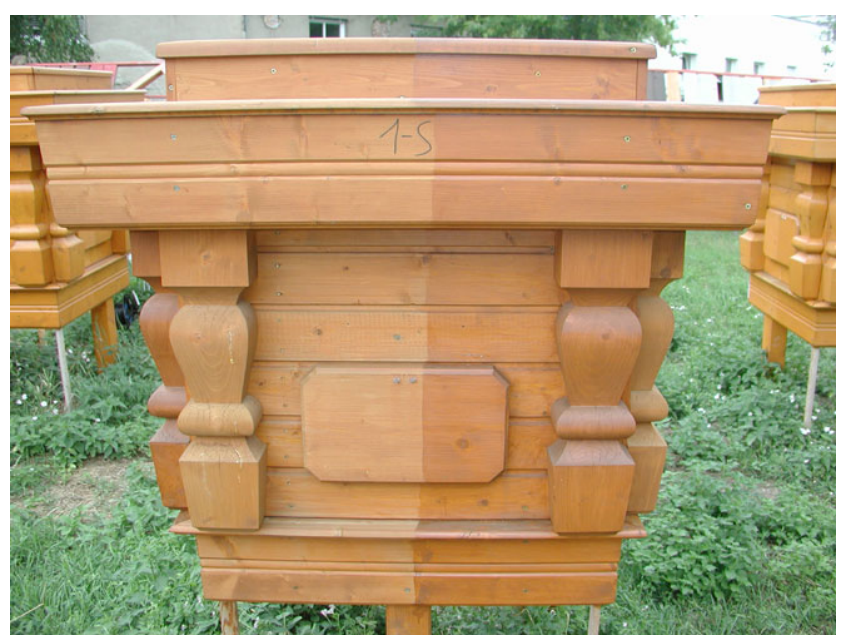

Fig. 1 Front view of balcony construction, side exposed to south; left side: original coating; right side: maintenance coating (applied after 18 months of exposure)

Abb. 1 Vorderansicht einer Balkonkonstruktion, nach Süden exponierte Seite; linke Seite: Erstbeschichtung; rechte Seite: Wartungsanstrich (nach 18 Monaten Bewitterung appliziert) 


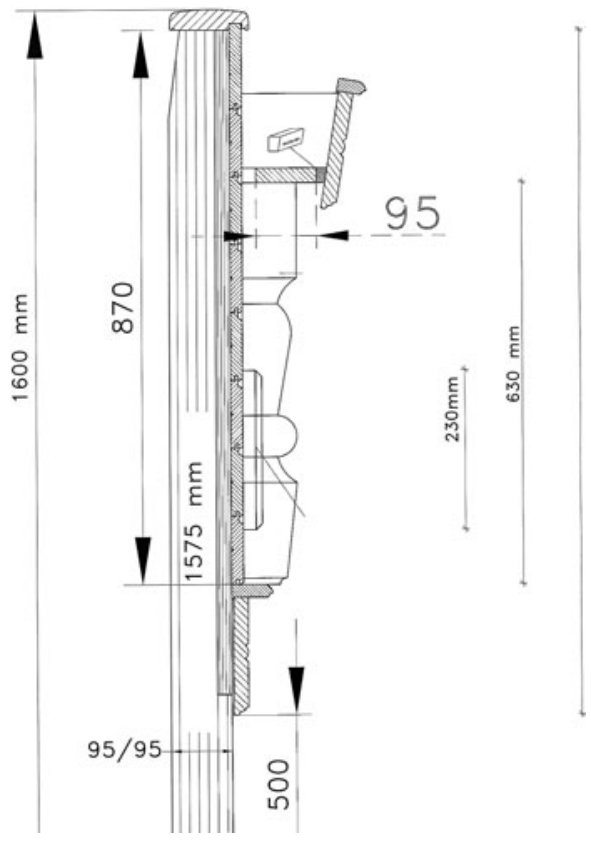

Fig. 2 Design of the balcony constructions (vertical section) Abb. 2 Konstruktion der Balkonaufbauten (vertikaler Schnitt)

commonly used to repair wood defects before coating application were placed into the wood. These constructions were chosen to reflect practical situations rather than standard testing procedures with ideal wood panels and thereby gather experience that is relevant in practice. The 15 coating systems were selected to represent the variety of products available on the market with regard to coating film thickness and transparency. They were applied either with brush, dipping or flow coating technique by industry partners and professional painters with suitable experience. The dry film thickness of the coatings was measured on samples taken from the finished constructions using microscopic measurements on cross sections according to EN ISO 2808 (2007), procedure $6 \mathrm{~A}$. A characterization of the coating systems is shown in Table 1.

Visual assessment of the coated surfaces on all parts of the balcony constructions was carried out after 18 and 24 months of natural weathering with a rating scale for general appearance according to EN ISO 4628-1 (2003), Table 1, where 0 indicates no perceptible change and 5 severe and intense change. All visible alterations of the coated surfaces, including changes in gloss or colour, cracking, flaking, blistering etc., were taken into account for this assessment.

After 18 months of natural weathering one half of each side (east, south, west) of the balcony parts was maintained by preparing the surfaces with light sanding, cleaning using a brush with bristles of brass and brush application of a coating material in one layer. For each construction a coating product suitable for the original coating system was used for maintenance. In most cases identical products were used for original and maintenance coating of the parts (Table 1). After 24 months of natural weathering the surfaces of the balcony parts were assessed visually and defects were recorded comparing the surfaces with and without maintenance coating. The development of coating defects after this period of weathering was sufficient to identify if maintenance was done at the proper time or if this action was too early or too late for the individual coating systems.

\section{Results}

\subsection{Influence of imperfect coating application}

On the industrially finished balcony constructions a few signs of imperfect coating application were observed that led to early alterations in weathering. For the systems with flow application (2, 5, 7, 8 and 9) on single elements from one end to the other, different states of weathering defects were observed after 18 months of exposure. It was figured out that the film thickness of the flow coated elements was distributed unequally, with one side showing smaller (during flow application on top) and the other side higher dry film thicknesses (during flow application on bottom). The areas with smaller film thickness showed defects earlier. Also uneven spreading rates during brush application led to some differences in weathering behavior, which was observed for systems 11,12 and 13 .

It came out that assembling the components before coating application of film forming systems was negative because during weathering moisture spread from a few uncoated areas below the coating film and ended up in local colour changes and flaking of the coating film.

\subsection{Influence of coating systems and maintenance procedures}

The coating systems showed marked differences in degradation after 18 months of natural weathering before application of the maintenance coatings as well as after 24 months of natural weathering. Ratings of general appearance according to EN ISO 4628-1 of all main components of the balcony constructions are listed in Table 2 . All coated surfaces showed at least minor alterations like changes in gloss or colour, superficial mould growth and dirt deposition, so that no surface was rated with a general appearance of zero (0). The most pronounced alterations were observed at the surfaces on the most severely exposed top sides of the hand rails of the balcony constructions, whereas all other parts were less degraded because of their vertical position and occasional protection by other parts. The maintenance coatings on semi-transparent coating systems resulted in 
Table 1 Description of coating systems and maintenance products

Tab. 1 Beschreibung der Beschichtungssysteme und Wartungsprodukte

\begin{tabular}{|c|c|c|c|c|c|c|}
\hline $\begin{array}{l}\text { System } \\
\text { No. }\end{array}$ & Characterization & Binder & $\begin{array}{l}\text { Wood } \\
\text { preserver }^{\mathrm{a}}\end{array}$ & $\begin{array}{l}\text { Target } \\
\text { spreading rate } \\
{\left[\mathrm{g} / \mathrm{m}^{2}\right]}\end{array}$ & $\begin{array}{l}\text { Film } \\
\text { thickness } \\
{[\mu \mathrm{m}]}\end{array}$ & $\begin{array}{l}\text { Maintenance } \\
\text { product } \\
(1 \times \text { brush })\end{array}$ \\
\hline \multirow[t]{2}{*}{1} & Primer & Acrylate resin & \multirow[t]{2}{*}{$\mathrm{B}, \mathrm{P}$} & $1 \times 160$ brush & \multirow[t]{2}{*}{69} & \multirow{2}{*}{$\begin{array}{l}\text { Opaque white medium } \\
\text { build top coat }\end{array}$} \\
\hline & $\begin{array}{l}\text { Opaque white high build } \\
\text { top coat }\end{array}$ & $\begin{array}{l}\text { Alkyd-acrylate-PUR- } \\
\text { resin }\end{array}$ & & $2 \times 125$ brush & & \\
\hline \multirow[t]{3}{*}{2} & $\begin{array}{l}\text { Vacuum Impregnation } \\
\text { (solvent borne) }\end{array}$ & Linseed oil alkyd resin & $\mathrm{B}, \mathrm{P}$ & $\begin{array}{l}\text { Vacuum } \\
\text { impregnation }\end{array}$ & \multirow[t]{3}{*}{130} & \multirow[t]{3}{*}{$\begin{array}{l}\text { Opaque white medium } \\
\text { build top coat }\end{array}$} \\
\hline & Primer & Acylate resin & - & $1 \times 120$ flow & & \\
\hline & $\begin{array}{l}\text { Opaque white medium } \\
\text { build top coat }\end{array}$ & Acylate resin & - & $2 \times 120$ flow & & \\
\hline \multirow[t]{2}{*}{3} & Impregnation & Alkyd resin & $\mathrm{B}$ & $1 \times 140$ brush & \multirow[t]{2}{*}{39} & \multirow{2}{*}{$\begin{array}{l}\text { Semi transparent low } \\
\text { build top coat }\end{array}$} \\
\hline & $\begin{array}{l}\text { Semi transparent low } \\
\text { build top coat }\end{array}$ & $\begin{array}{l}\text { Acrylate-copolymer- } \\
\text { dispersion }\end{array}$ & - & $3 \times 85$ brush & & \\
\hline \multirow[t]{3}{*}{4} & Impregnation & Modified linseed oil & $\mathrm{B}, \mathrm{P}$ & $1 \times 200$ dipping & \multirow[t]{3}{*}{45} & \multirow{3}{*}{$\begin{array}{l}\text { Semi transparent low } \\
\text { build top coat }\end{array}$} \\
\hline & Primer & $\begin{array}{l}\text { Alkyd-acrylate } \\
\text { dispersion }\end{array}$ & $\mathrm{B}, \mathrm{P}$ & $1 \times 110$ dipping & & \\
\hline & $\begin{array}{l}\text { Semi transparent medium } \\
\text { build top coat }\end{array}$ & $\begin{array}{l}\text { Acrylate- and oil } \\
\text { modified } \\
\text { PUR-dispersion }\end{array}$ & B & $2 \times 100$ dipping & & \\
\hline \multirow[t]{3}{*}{5} & Impregnation & Alkyd resin & $\mathrm{B}$ & $1 \times 140$ brush & \multirow[t]{3}{*}{90} & \multirow{3}{*}{$\begin{array}{l}\text { Semi transparent } \\
\text { medium build top coat }\end{array}$} \\
\hline & Primer & Acrylate-copolymer & $\mathrm{B}$ & $1 \times 70$ brush & & \\
\hline & $\begin{array}{l}\text { Semi transparent medium } \\
\text { build top coat }\end{array}$ & Acrylate-dispersion & & $2 \times 70$ flow & & \\
\hline \multirow[t]{2}{*}{6} & Impregnation & Alkyd resin & B & $1 \times 140$ brush & \multirow[t]{2}{*}{38} & \multirow{2}{*}{$\begin{array}{l}\text { Semi transparent low } \\
\text { build top coat }\end{array}$} \\
\hline & $\begin{array}{l}\text { Semi transparent low } \\
\text { build top coat }\end{array}$ & Hybrid resin & & $\begin{array}{l}1 \times 140 \text { brush } \\
2 \times 105 \text { brush }\end{array}$ & & \\
\hline \multirow[t]{3}{*}{7} & $\begin{array}{l}\text { Vacuum Impregnation } \\
\text { (solvent borne) }\end{array}$ & Linseed oil alkyd resin & $\mathrm{B}, \mathrm{P}$ & $\begin{array}{l}\text { Vacuum } \\
\text { impregnation }\end{array}$ & \multirow[t]{3}{*}{72} & \multirow[t]{3}{*}{$\begin{array}{l}\text { Semi transparent } \\
\text { medium build top coat }\end{array}$} \\
\hline & Primer & Acylate resin & $\mathrm{B}, \mathrm{P}$ & $1 \times 85$ flow & & \\
\hline & $\begin{array}{l}\text { Semi transparent medium } \\
\text { build top coat }\end{array}$ & Acylate resin & & $2 \times 120$ flow & & \\
\hline \multirow[t]{3}{*}{8} & Impregnation & Acylate resin & $\mathrm{B}, \mathrm{P}$ & $1 \times$ flow & \multirow[t]{3}{*}{68} & \multirow{3}{*}{$\begin{array}{l}\text { Semi transparent } \\
\text { medium build top coat }\end{array}$} \\
\hline & Primer & Acylate resin & $\mathrm{B}, \mathrm{P}$ & $1 \times 85$ flow & & \\
\hline & $\begin{array}{l}\text { Semi transparent medium } \\
\text { build top coat }\end{array}$ & Acylate resin & & $2 \times 120$ flow & & \\
\hline \multirow[t]{3}{*}{9} & Impregnation & Modified linseed oil & $\mathrm{B}, \mathrm{P}$ & $1 \times 200$ brush & \multirow[t]{3}{*}{95} & \multirow{3}{*}{$\begin{array}{l}\text { Semi transparent low } \\
\text { build top coat }\end{array}$} \\
\hline & Primer & $\begin{array}{l}\text { Alkyd- and acrylate } \\
\text { dispersion }\end{array}$ & $\mathrm{B}, \mathrm{P}$ & $1 \times 110$ brush & & \\
\hline & $\begin{array}{l}\text { Semi transparent medium } \\
\text { build top coat }\end{array}$ & Acrylate dispersion & - & $2 \times 100$ brush & & \\
\hline \multirow[t]{3}{*}{10} & Impregnation & Modified linseed oil & $\mathrm{B}, \mathrm{P}$ & $1 \times 200$ brush & \multirow[t]{3}{*}{37} & Semi transparent low \\
\hline & Primer & $\begin{array}{l}\text { Alkyd-acrylate } \\
\text { dispersion }\end{array}$ & $\mathrm{B}, \mathrm{P}$ & $1 \times 110$ brush & & build top coat \\
\hline & $\begin{array}{l}\text { Semi transparent low } \\
\text { build top coat }\end{array}$ & Acrylate-alkyd-resin & $\mathrm{B}$ & $2 \times 110$ brush & & \\
\hline 11 & Primer & Hybrid resin & $\mathrm{B}$ & $1 \times 140$ dipping & 39 & Semi transparent \\
\hline & $\begin{array}{l}\text { Semi transparent } \\
\text { intermediate coat }\end{array}$ & Hybrid resin & B & $1 \times 180$ dipping & & medium build top-coat \\
\hline & $\begin{array}{l}\text { Semi transparent medium } \\
\text { build top-coat }\end{array}$ & $\begin{array}{l}\text { Acrylate-PU- } \\
\text { dispersion }\end{array}$ & & $1 \times 130$ brush & & \\
\hline
\end{tabular}


Table 1 (Continued)

Tab. 1 (Fortgesetzt)

\begin{tabular}{|c|c|c|c|c|c|c|}
\hline $\begin{array}{l}\text { System } \\
\text { No. }\end{array}$ & Characterization & Binder & $\begin{array}{l}\text { Wood } \\
\text { preserver }^{\mathrm{a}}\end{array}$ & $\begin{array}{l}\text { Target } \\
\text { spreading rate } \\
{\left[\mathrm{g} / \mathrm{m}^{2}\right]}\end{array}$ & $\begin{array}{l}\text { Film } \\
\text { thickness } \\
{[\mu \mathrm{m}]}\end{array}$ & $\begin{array}{l}\text { Maintenance } \\
\text { product } \\
(1 \times \text { brush })\end{array}$ \\
\hline \multirow[t]{3}{*}{12} & Primer & Hybrid resin & B & $1 \times 140$ dipping & \multirow[t]{3}{*}{52} & \multirow{3}{*}{$\begin{array}{l}\text { Semi transparent high } \\
\text { build top-coat }\end{array}$} \\
\hline & $\begin{array}{l}\text { Semi transparent } \\
\text { intermediate coat }\end{array}$ & Hybrid resin & B & $1 \times 180$ dipping & & \\
\hline & $\begin{array}{l}\text { Semi transparent high } \\
\text { build top-coat }\end{array}$ & Hybrid resin & & $1 \times 70$ brush & & \\
\hline \multirow[t]{2}{*}{13} & $\begin{array}{l}\text { Semi transparent low } \\
\text { build coat }\end{array}$ & Alkyd-acrylate-resin & B & $1 \times 90$ brush & \multirow[t]{2}{*}{30} & \multirow[t]{2}{*}{$\begin{array}{l}\text { Semi transparent low } \\
\text { build coat }\end{array}$} \\
\hline & $\begin{array}{l}\text { Semi transparent low } \\
\text { build coat }\end{array}$ & Alkyd-acrylate-resin & B & $1 \times 90$ brush & & \\
\hline 14 & $\begin{array}{l}\text { Semi transparent low } \\
\text { build coat }\end{array}$ & Alkyd-acrylate-resin & $\mathrm{B}, \mathrm{P}, \mathrm{W}$ & $2 \times 200$ brush & 27 & $\begin{array}{l}\text { Semi transparent low } \\
\text { build coat }\end{array}$ \\
\hline 15 & $\begin{array}{l}\text { Semi transparent low } \\
\text { build coat }\end{array}$ & Alkyd resin & $\mathrm{B}, \mathrm{P}$ & $2 \times 200$ brush & 32 & $\begin{array}{l}\text { Semi transparent low } \\
\text { build coat, (solvent } \\
\text { borne) }\end{array}$ \\
\hline $\mathrm{U}$ & Uncoated & - & - & - & & \\
\hline
\end{tabular}

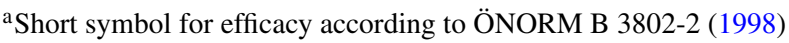

$\mathrm{B}$ : wood discoloring fungi; $\mathrm{P}$ : wood destroying fungi

Table 2 General appearance score according to EN ISO 4628-1 after 18 and 24 months exposure on surfaces with and without maintenance Tab. 2 Bewertung des allgemeinen Aussehens gemäß EN ISO 4628-1 nach 18- und 24-monatiger Bewitterung an Oberflächen mit und ohne Wartung

\begin{tabular}{|c|c|c|c|c|c|c|c|c|c|c|c|c|}
\hline \multirow{2}{*}{$\begin{array}{l}\text { System } \\
\text { No. } \\
\text { Time in } \\
\text { exposure }\end{array}$} & \multicolumn{3}{|c|}{$\begin{array}{l}\text { Horizontal areas } \\
\text { at hand rails }\end{array}$} & \multicolumn{3}{|c|}{$\begin{array}{l}\text { Rounded areas at } \\
\text { banisters }\end{array}$} & \multicolumn{3}{|c|}{$\begin{array}{l}\text { Vertical areas on } \\
\text { front boards }\end{array}$} & \multicolumn{3}{|c|}{$\begin{array}{l}\text { Vertical areas on } \\
\text { cladding }\end{array}$} \\
\hline & $18 \mathrm{Mo.}$ & 24 Mo. & 24 Mo. & 18 Mo. & 24 Mo. & 24 Mo. & $18 \mathrm{Mo.}$ & 24 Mo. & 24 Mo. & 18 Mo. & 24 Mo. & $24 \mathrm{Mo}$ \\
\hline Maintenance & No & No & Yes & No & No & Yes & No & No & Yes & No & No & Yes \\
\hline 1 & 1 & 1 & 1 & 1 & 1 & 1 & 1 & 1 & 1 & 1 & 1 & 1 \\
\hline 2 & 1 & 1 & 1 & 1 & 1 & 1 & 1 & 1 & 1 & 1 & 1 & 1 \\
\hline 3 & 1 & 1 & 1 & 1 & 1 & 1 & 1 & 1 & 1 & 1 & 1 & 1 \\
\hline 4 & 1 & 1 & 1 & 1 & 1 & 1 & 1 & 1 & 1 & 1 & 1 & 1 \\
\hline 5 & 1 & 2 & 1 & 1 & 1 & 1 & 1 & 1 & 1 & 1 & 1 & 1 \\
\hline 6 & 1 & 2 & 1 & 1 & 2 & 1 & 1 & 1 & 1 & 1 & 1 & 1 \\
\hline 7 & 2 & 2 & 1 & 2 & 2 & 1 & 1 & 1 & 1 & 2 & 2 & 1 \\
\hline 8 & 2 & 2 & 1 & 1 & 2 & 1 & 1 & 1 & 1 & 2 & 2 & 1 \\
\hline 9 & 2 & 2 & 1 & 1 & 1 & 1 & 1 & 1 & 1 & 1 & 1 & 1 \\
\hline 10 & 2 & 3 & 1 & 1 & 1 & 1 & 1 & 1 & 1 & 1 & 1 & 1 \\
\hline 11 & 3 & 3 & 3 & 1 & 1 & 1 & 1 & 1 & 1 & 1 & 2 & 1 \\
\hline 12 & 3 & 3 & 3 & 1 & 1 & 1 & 1 & 1 & 1 & 1 & 2 & 1 \\
\hline 13 & 3 & 4 & 3 & 1 & 1 & 1 & 2 & 3 & 2 & 3 & 3 & 2 \\
\hline 14 & 3 & 4 & 2 & 3 & 4 & 2 & 2 & 2 & 2 & 2 & 3 & 2 \\
\hline 15 & 3 & 4 & 3 & 4 & 4 & 3 & 2 & 3 & 1 & 2 & 3 & 1 \\
\hline Uncoated & 5 & 5 & 5 & 5 & 5 & 5 & 5 & 5 & 5 & 5 & 5 & 5 \\
\hline
\end{tabular}


slightly darker colours of the surfaces. With the white coating systems the original colour was retained and refreshed by applying the maintenance coating.

Coating systems 1, 2, 3 and 4 were in very good condition before application of the maintenance coating as well as after 24 months of weathering. There were no visible defects of the coating films. The two opaque white coating systems 1 and 2 were the most durable ones, while amongst the semi transparent systems only systems 3 and 4 showed no visible film defects after that period of weathering on the top sides of the hand rails.

For coating systems 5 and 6 the original coating showed minor defects such as small cracks and discolorations around them while on the maintained surfaces no defects were visible, also in the regions around knots and patches in the wood. The coating systems 11 and 12 comprised severe defects on the original surface and somewhat less pronounced defects on the part with the maintenance coating.

The coating systems 13,14 and 15 with dry film thicknesses around $30 \mu \mathrm{m}$ can be regarded as non film forming systems and, hence, they revealed a different weathering behavior compared to all other coating systems used in this study. Their surfaces showed numerous coarse and fine cracks in the wood and the original surfaces became matt after 24 months of weathering. However, no colour differences and no flaking were observed in the regions of wood cracks and patches. The surfaces with the maintenance coating also comprised cracks in a similar quantity and size. The matt appearance was, however, replaced by a refreshed surface, clearly darker in colour than the original one.

It was not found that the additional vacuum impregnation at the semi transparent system 7 contributed to better results in weathering than system 8 which was made of the same primer and topcoat.

\section{Discussion}

\subsection{Durability and maintenance procedures}

The results obtained in the weathering trials with balcony constructions revealed differences in durability and weathering behavior of typical coating systems for exterior wood. As expected it was found that the opaque white coating systems 1 and 2 were the most durable ones, showing no defects after 24 months of weathering on the most severely exposed top sides of the hand rails in nearly horizontal position. With these coating systems maintenance was easy and the original colour was retained and refreshed very well. Because of the high durability of the coatings the limit state for maintenance was not reached after 18 months of exposure since the coatings were still in very good shape. Therefore, maintenance was carried out too early on these coating systems and it could have been done after longer periods of exposure.
The semi transparent coating systems 3 and 4 revealed exceptionally high durability; the maintenance coating was applied at an early stage and could have been applied after a longer period of weathering. At systems with lower durability, like systems 7 and 9, a maintenance interval of 18 months after the start of exposure was optimal on the top side of the hand rails because on the maintained surfaces further degradation was prevented while the surfaces without maintenance showed marked alterations in the following six months of exposure. For other less durable systems, like systems 11 and 12, the maintenance coatings were applied on partly degraded coating films with visible defects. Maintenance should have been applied earlier on these surfaces, before visible defects occurred. The coatings have passed the maintenance interval, their condition has proceeded beyond that limit state, and they would have required renovation to repair the defects. In the present stage, however, maintenance prevented further development of the film defects, but the semi transparent maintenance coatings were not able to hide discolorations already present on the surfaces.

Very different characteristics were observed with the low build coating systems 13,14 and 15. Because of their non film forming character surface degradation was very uniform without local discoloration or flaking. The appearance of many cracks in the wood surfaces required maintenance, which was easy and effective in refreshing the coated surfaces and preventing further degradation. That indicates that limit states of non film forming coatings are different from those of film forming ones.

The maintenance procedures used were simple and effective for all coating systems. Applying the maintenance coatings was beneficial to prolong a coating's service life and to repair the observed deficiencies from imperfect coating application. Those deficiencies were present in spite of the parts being finished by professional painters and experienced industry partners. This stresses the importance of maintenance of coated wood components in exterior use in proper time intervals. However, it remains difficult to determine the right period for maintenance work, in particular when definitions of limit states are lacking, because maintenance is needed before visible defects occur or at least visible defects are very small and do not require removal of the original coating film.

\subsection{Definition of limit states}

The experience gathered with the investigated coating systems on balcony constructions showed that durability of coatings systems on wood is characterized by reaching different types of limit states where specific properties become unacceptable for the end-user or from a technical point of view and therefore action is needed to restore them. Table 3 
Table 3 Definition of limit states for wood coating systems

Tab. 3 Definition von Grenzzuständen für Holzbeschichtungssysteme

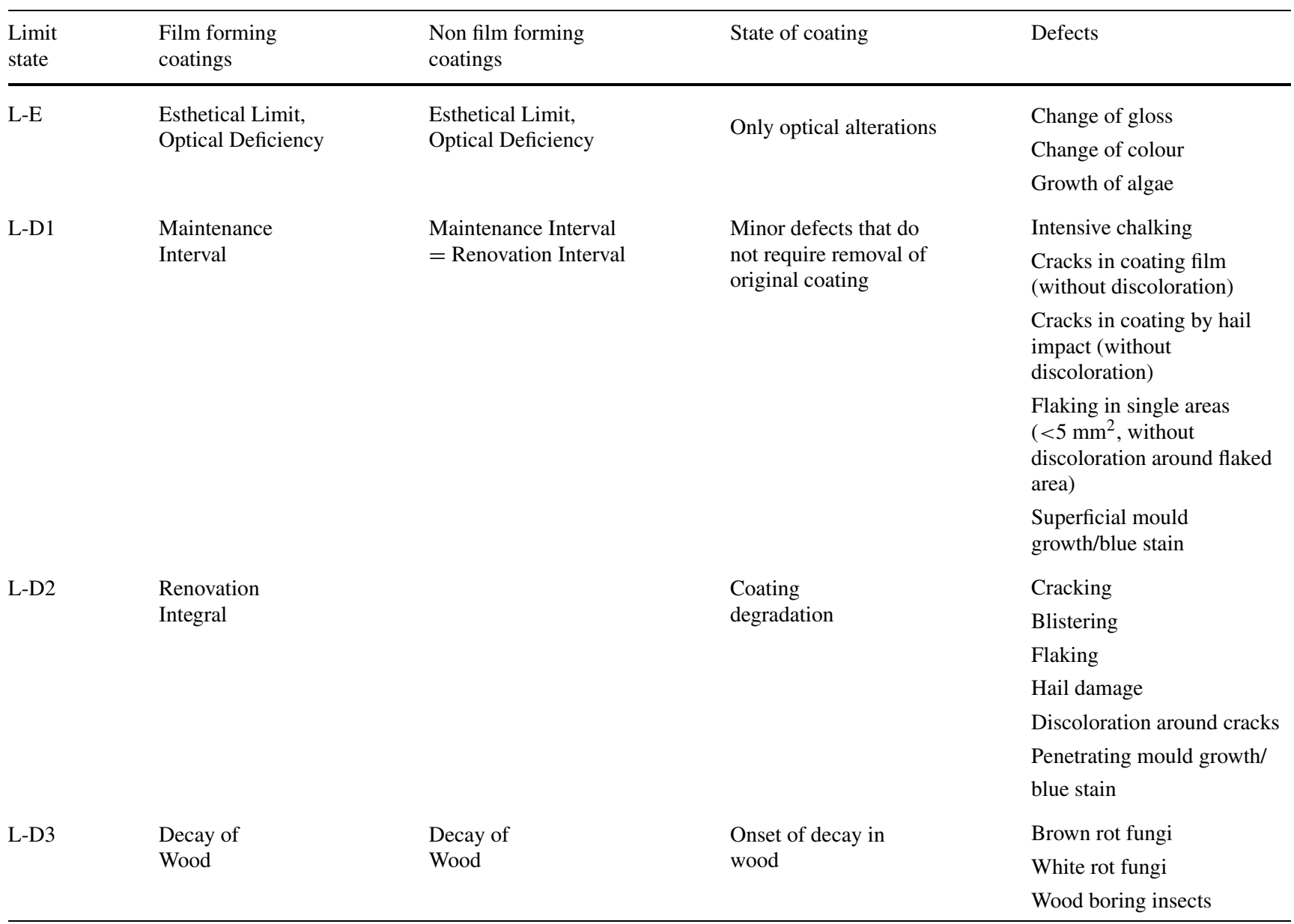

suggests a series of limit states for coating systems on wood that can be reached consequently over time of weathering. The relevant coating properties can be divided into those affecting only the esthetical appearance of a coated surface and those influencing the technical functions of the coating system or the wood components. Therefore, the table includes esthetical limits (L-E) and durability limits (L-D) separately. The latter can be further separated into three levels of durability where the levels L-D1 and L-D2 are related to the coating system itself and the limit state L-D3 indicates the durability of the coated substrate, i.e. the wood component, by the onset of decay in wood, which is unlikely to happen with proper construction and wood preservation. The occurrence of these limit states is indicated by typical and tolerated defects that are listed in the last column of Table 3. The acceptance of esthetical factors depends on subjective impression and therefore emphasis is put on technical defects of coatings. For most of these defects their presence or absence is decisive for the incidence of a limit state and not their quantity or size. For flaking where the quantity is relevant to decide if maintenance or renovation is needed, tolerated values are included in Table 3. Thereby it is intended to allow simple application of these definitions in practice without the need of quantitative test methods or ratings.

For film forming coating systems two durability limits must be defined depending on the status of coating degradation and the work needed either for maintenance or for renovation of the coating system. Minor degradation without visually detectable defects can be acceptable until a maintenance coating is needed. This indicates the maintenance interval of the coating system as limit state L-D1. It is known that even for experts it is sometimes difficult to determine the proper time interval to apply a maintenance coating on top of an aged coating film. With the definition of maintenance as stated in the introduction (MacKenzie et al. 2007) and based on the results of the maintenance trials it becomes obvious that maintenance work contributes to prolong service life of a coating and specified maintenance intervals are therefore needed. If the end-user abstains from maintenance, ongoing degradation of the coating will lead to severe defects and finally the loss of technical functions of the coat- 
ing (De Meijer 2002). This eventually requires removal of the degraded coating film and the application of a new coating to protect the wood component again. Therefore, maintenance should be considered as a cheap and preventive process to avoid renovation which is more time-consuming and expensive. Regular inspections are recommended in a maintenance scheme.

The results showed that the characteristics of film forming coatings and non film forming coatings are different. With non film forming coatings, flaking and esthetically unacceptable local discoloration are unlikely. Hence, the alterations due to weathering are usually very uniformly distributed over a surface. However, due to the high water permeability of these coatings cracking of wood is not prevented. These characteristics lead to the conclusion that with non film forming systems no separation between maintenance intervals and renovation intervals can be defined and there is only one limit state of coating durability (L-D1 = L-D2) which is shown in Table 3.

\section{Conclusion}

The results obtained in weathering trials with balcony constructions with and without maintenance of the coatings revealed differences in durability and weathering behavior of typical coating systems for exterior wood. It was found that the opaque white coating systems were the most durable ones reaching long intervals of required maintenance. For systems with lower durability on the maintained surfaces further degradation of the coatings was prevented while the surfaces without maintenance showed marked alterations in the following six months of exposure. Different characteristics were observed for film forming and non film forming semi-transparent varnishes where surface degradation was very uniform without local discoloration or flaking but many cracks in the wood surfaces with the non film forming systems. Applying the maintenance coatings was beneficial to prolong a coating's service life and to repair the observed deficiencies from imperfect coating application.

Definitions of a series of limit states for coating systems on wood that can be reached consequently over time of weathering were suggested including esthetical limits and three levels of durability limits. Film forming coatings can reach two durability limits, i.e. the maintenance interval and the renovation interval. For non film forming coatings there is only one limit state of coating durability where maintenance is needed. The third durability limit is related to the coated substrate, i.e. the wood component, by the onset of decay in wood.
Acknowledgements The authors gratefully acknowledge the financial support of WoodWisdom-Net (www.woodwisdom.net), the Austrian Research Promotion Agency (FFG) and the wood industry partnership Building with Wood for funding the research work within project "WoodExter". This work forms part of that project. The "WoodExter" research partners are thanked for their cooperation and collaboration in this project.

\section{References}

Brandstätter M, Neumüller A, Scheibenreiter J, Spatt M, Buchgraber M, Grüll G (2002) Holzfassaden. Holzforschung Austria, Wien

Bulian F, Magagnoli C, Tirelli P (2004) The effects of ageing on mechanical and spectroscopic properties of free films of exterior wood varnishes. In: Proceedings 4th international woodcoatings congress, PRA, Hampton

De Meijer M (2002) Mechanisms of failure in exterior wood coatings. In: Proceedings 3rd international woodcoatings congress, PRA, Hampton

Ekstedt J (2002) Studies on the barrier properties of wood coatings. Royal Institute of Technology, Stockholm

EN ISO 4628-1 (2003) Paints and varnishes - evaluation of degradation of coatings - designation of quantity and size of defects, and of intensity of uniform changes in appearance, Part 1: General introduction and designation system

EN ISO 2808 (2007) Paints and varnishes-determination of film thickness

Englund F (2009) Standardisation related to service life planningstate of the art report WoodExter. SP Trätek, Stockholm

European Construction Products Directive (1989) (89/106/EEC)

French standard T30-806 (1991) Paints and varnishes-painting of building - specimen contract for periodic maintenance

Grüll G (2003) Holzfenster - Pflege, Wartung und Renovierung. Renovation 2:28-30

Hayoz P, Peter W, Rogez D (2003) A new innovative stabilization method for the protection of natural wood. Prog Org Coat 48(24):297-309

Kutz M (2005) Handbook of environmental degradation of materials. William Andrew Pub, Norwich

MacKenzie CE, Wang CH, Leicester RH, Foliente GC, Nguyen MN (2007) Timber service life design guide. Forest and Wood Products Australia Limited, Victoria

ÖNORM B 3802-2 (1998) Protection of timber used in buildingschemical protecting of timber

Richter K (1988) Effizienter Oberflächenschutz von Holz im Außenbereich. Dtsch Bauz 22(4):88-94

Richter K (2006) Wooden facades: systems, durability and environmental assessment. In: Towards the city surface of tomorrow. Technische Universität Wien, Wien

Schaller C, Rogez D (2007) New approaches in wood coating stabilization. J Coat Technol Res 4(4):401-409

Schober KP, Auer C, Grüll G (2006) Balkone und Terrassenbeläge aus Holz, 1 edn. HFA-Schriftenreihe, vol 12. Holzforschung Wien,

Sell J (2003) Beschichtungen von Holzfassaden - ein Überblick. In: Proceed. Holzschutztagung der DGfH, vol 23. DGfH, München

Tretter A (2004) Holzlackschäden. Beschichtungsmängel an Fenstern Erkennen - Vermeiden - Sanieren. DRW-Verlag, LeinfeldenEchterdingen

Tscherne F, Grüll G (2005) So vermeidet man Frühschäden - Pflege und Wartung von Holzfensterbeschichtungen. Holzforschung Austria - Magazin für den Holzbereich 3(1):8-9 